\title{
NILAI PENDIDIKAN KARAKTER PADA TINDAK TUTUR ILUKOSI DALAM PODCAST DEDDY CORBUZEIR BERSAMA SYEKH ALI JABER
}

\author{
Rudi $^{1}$, Joko Widodo ${ }^{2}$ \\ Universitas Muhammadiyah Malang, Jawa Timur, Indonesia ${ }^{1,2}$ \\ rudikisara15@gmail.com ${ }^{1}$,joko_w@umm.ac.id ${ }^{2}$
}

\begin{abstract}
This study aims to describe the types of illocutionary speech and the value of character education in the speech on the video podcast of Deddy Corbuzier with Syekh Ali Jaber. This type of qualitative research with a descriptive approach. Sources of research data are utterances spoken by Deddy Corbuzier, Syekh Ali Jaber, and Gus Mifta in Deddy Corbuzier's Podcast video with Syekh Ali Jaber on Deddy Corbuzier youtube channel. The research data is in the form of sentences that reflect illocutionary speech acts and the value of character education. The data collection technique is done by using observation technique. The data analysis technique uses the Miles and Huberman model, which includes the stages of data reduction, data presentation, and conclusion/verification. The results showed: (1) types of illocutionary speech acts include assertive, directive, commissive, and expressive speech acts. (2) The value of character education includes the character of social care, religion, honesty, tolerance, love for the country, creativity, democracy, and love peace. Based on the findings, the dominant character education value in the speech activity is the value of religious character. This can happen, because it is influenced by the background of the speaker and the context of the speech.
\end{abstract}

Keywords: the value of character education, illocutionary speech act, pragmatics

\begin{abstract}
ABSTRAK
Penelitian ini bertujuan mendeskripsikan jenis tidak tutur ilokusi, dan nilai pendidikan karakter dalam tuturan dalam video podcast Deddy Corbuzier bersama Syekh Ali Jaber. Jenis penelitian kualitatif dengan pendekatan deskriptif. Sumber data penelitian adalah tuturan yang dituturkan oleh Deddy Corbuzier, Syekh Ali Jaber, dan Gus Mifta dalam video Podcast Deddy Corbuzier bersama Syekh Ali Jaber di kanal youtube Deddy Corbuzier. Adapun data penelitian berupa kalimat yang mencerminkan tindak tutur ilokusi dan nilai pendidikan karakter. Teknik pengumpulan data dilakukan dengan teknik observasi. Teknik analisis data menggunakan model Miles dan Huberman, yang meliputi tahapan reduksi data, penyajian data, dan penarikan kesimpulan/verifikasi. Hasil penelitian menunjukkan: (1) jenis tidak tutur ilokusi meliputi tindak tutur asertif, direktif, komisif, dan ekspresif. (2) Nilai pendidikan karakter mencangkup karakter peduli sosial, religius, jujur, toleransi, cinta tanah air, kreatif, demokrasi, dan cinta damai. Berdasarkan hasil temuan, nilai pendidikan karakter yang dominan pada kegiatan tuturan tersebut, yaitu nilai karakter religius. Hal tersebut dapat terjadi, karena dipengaruhi oleh latar belakang penutur dan konteks tuturan.
\end{abstract}

Kata kunci: nilai pendidikan karakter, tindak tutur ilokusi, pragmatik.

\section{PENDAHULUAN}

Hakikat manusia dalam konteks hubungan sosial dengan manusia lainnya tidak terlepas dari aktivitas interaksi. Interaksi tersebut dilakukan untuk menyampaikan suatu maksud, baik dalam tujuan membangun relasi dengan induvidu lain maupun menyampaikan suatu maksud tertentu (Nasrullah, 2018) . Dalam aktivitas interaksi

Nilai Pendidikan Karakter Pada Tindak Tutur Ilukosi dalam Podcast Deddy Corbuzeir 92

Bersama Syekh Ali Jaber 
manusia menggunakan bahasa sebagai sarana untuk menyampaikan suatu makna kepada mitra tutur (Arisandy, Rizkika, \& Astika, 2019). Berdasarkan pernyataan tersebut, mengisyarakan bahwa bahasa dalam realitas kehidupan memiliki fungsi sebagai alat yang digunakan untuk berkomunikasi dengan orang lain.

Lebih lanjut dapat dicermati bahwa bahasa merupakan sarana berkomunikasi dalam bentuk simbol bunyi untuk mengekspresikan perasaan. Hal tersebut dipertegas oleh pendapat Aminah, Zuraida dan Emilda (2020), fungsi bahasa salah satunya adalah sebagai alat komunikasi untuk mengungkapkan perasaan, makna, dan membangun kerja sama sebagai makhluk sosial. Sementara menurut Putri dan Zulaeha (2020), bahasa bukan alat dan media komunikasi satusatunya, melainkan penggunaan bahasa lebih efektif dan efisien untuk menyampaikan suatu maksud/tujuan tertentu dalam sebuah interaksi (percakapan). Tanpa adanya media bahasa dalam kegiatan interaksi/komunikasi, maka komunikasi yang dilakukan tidak akan tersistematis dengan baik.

Perangai seseorang dalam kegiatan berkomunikasi merupakan cerminan identitas diri dan karakter. Karakter merupakan sistem tata nilai yang tertanam dalam diri seseorang serta yang menjadi ciri khas kepribadian, sikap, dan perilaku dengan orang lain (Ali, 2018). Chanifah dan Samsudin (2019) mempertegas pendapat Ali, dengan mengatakan bahwa karakter merupakan kekuatan mental dalam diri seseorang yang mendorong dalam bersikap, bertindak, dan bertutur kata sehingga menjadikan pembeda dengan orang lain.

Kualitas karakter menjadi modal dasar bagi seseorang untuk menjadi manusia yang berbudi pekerti. Adanya karakter yang kuat pada diri seseorang menjadi kunci utama keberhasilan dalam kehidupan, baik secara personal maupun bagi bangsa (Omari dalam Pratama, 2020). Dengan kata lain, melemahnya karakter dalam jiwa seseorang dapat mengakibatkan mudah melakukan tindakan kriminalitas, karena tidak ada kontrol emosi.

Dewasa ini, marak terjadi pelanggaran pada nilai-nilai karakter di kalangan masyarakat. Hal tersebut dapat dilihat berdasarkan pemberitahuan media sosial. Pertama, kasus perundungan yang dilalukan oleh beberapa remaja putri di Cilacap, perundungan dilakukan dengan kekerasan fisik dan kekerasan verbal pada korban (Banyumas \& Zain, 2020). Kedua, pencabulan yang dilakukan oleh guru mengaji terhadap lima muridnya di Serang (Nurhadi, 2020). Ketiga, meningkatnya kasus kriminalitas di dunia maya, yang dapat dilihat berdasarkan data Direktorat Tindak Pidana Siber terdapat 4.656 kasus yang ditangani Bareskrim Polri pada periode Januari sampai November 2020, yang mencangkup kasus pencemaran nama baik, penipuan, pornografi, akses ilegal, ujaran kebencian, hoaks, manipulasi data, dan pengancaman (CNN Indonesia, 2020). Fenomena tersebut, mencerminkan adanya degradasi nilai-nilai karakter di masyarakat saat ini. Oleh karena itu, penelitian ini penting dilakukan dengan beberapa alasan, yaitu: (1) dapat mengamati nilai-nilai pendidikan karakter dalam tuturan, (2) memberikan edukasi/pengajaran terhadap masyarakat atau pembaca dalam merealisasikan nilai pendidikan karakter di kehidupan sehari-hari, dan (3) sebagai pedoman dan bahan literasi pembinaan pendidikan karakter.

Pembentukan karakter sangat esensial untuk membentuk kepribadian yang baik, dengan cara pendidikan karakter. Hal ini dipertegas oleh Handayani, Megawati dan Malia (2016), mengatakan upaya untuk membentuk karakter yang baik pada diri seseorang, maka penting dilakukan pendidikan karakter. Pada dasarnya pendidikan karakter dapat diartikan sebagai bentuk ikhtiar yang dilakukan untuk mendewasakan sifat, akhlak, kepribadian, dan budi pekerti seseorang (Hendriana \& Jacobus, 2016). Dalam ruang lingkung pendidikan formal, pendidikan karakter merupakan usaha mendasar yang dilakukan oleh pengajar untuk menciptakan iklim belajar sesuai kebutuhan pengembangan diri peserta didik, supaya berkarakter yang baik (Islam, 2017). Orientasi pendidikan karakter pada pengembangan tiga aspek, yaitu sikap, pengetahuan dan keterampilan, melalui proses menanamkan kebiasaan-kebiasaan yang baik terhadap siswa (Purwanti, 2017).

Pengembangan pendidikan karakter dapat dilakukan dalam lingkungan keluarga, masyarakat, dan lembaga sekolah. Suprayitno dan Wahyudi (2020), mengatakan ruang lingkup pendidikan karakter mencangkup dua aspek, (1) 
aspek dalam diri manusia, yaitu olah pikir, olah raga, dan olah hati, dan (2) aspek yang berada di luar manusia/konteks interaksi dengan orang lain, baik interaksi lingkungan keluarga, sekolah, dan masyarakat. Selain itu, pengembangan pendidikan karakter dapat dilakukan dengan pemanfaatan media sosial sebagai sarana menyampaikan informasi yang mengandung nilai-nilai pendidikan karakter bagi pembaca/masyarakat.

Salah satu media sosial (konten) yang sarat akan nilai-nilai pendidikan karakter adalah podcast Deddy Courbuzeir bersama Syekh Ali Jaber di kanal youtube. Konten ini menceritakan kronologi musibah yang dialami oleh Syekh Ali Jaber. Dalam menghadapi musibah tersebut, upaya yang dilakukan oleh Syekh Ali Jaber yaitu tawakal, serta membangun relasi yang baik terhadap sesama. Selain itu, Syekh Ali Jaber memberikan nasihat-nasihat untuk saling memaafkan, menoleransi, dan ikhlas pada setiap ujian yang dihadapi. Dari hal itu, mencerminkan nilai-nilai pendidikan karakter pada tuturan Syekh Ali Jaber.

Konten ini dipilih dengan beberapa alasan. Pertama, kanal youtube Deddy Corbuzier pada bulan Januari 2021 tercatat jumlah subscribe mencapai 12,9 juta. Kedua, podcast Deddy Corbuzier bersama Syekh Ali Jaber sudah ditonton sebanyak 17 juta penonton pada bulan Januari 2021. Ketiga, podcast tersebut mencerminkan nilai-nilai pendidikan karakter yang sangat esensial dalam kehidupan bermasyarakat. Hal tersebut menarik penulis untuk menganalisis video podcast Deddy Corbuzier.

Aktivitas komunikasi atau interaksi pada podcast Deddy Corbuzeir bersama Syekh Ali Jaber tidak terlepas dari penggunaan bahasa untuk menyampaikan pesan. Realisasi bahasa dalam komunikasi diwujudkan melalui tuturan/ujaran yang dilakukan penutur terhadap mitra tutur dengan maksud tertentu. Secara pragmatis, tuturan/kegiatan berbahasa yang dilakukan oleh penutur lazim disebut sebagai tindak tutur (Ekawati, 2017). Tindak tutur merupakan suatu perbuatan yang ditampilkan melalui percakapan (ujaran) penutur (Yule dalam Ramadhanti dan Mujianto, 2020). Orientasi tindak tutur yaitu terhadap makna/arti tindakan dalam ujaran (Nuramila, 2020). Oleh karena itu, tindak tutur sangat penting dalam kegiatan komunikasi di kehidupan sehari-hari.

Secara pragmatis, tindak tutur dikelompokkan menjadi tiga jenis, yaitu ilokusi, lokusi, dan perkolusi (Saputri \& Rahmawati, 2020). Adapaun dalam penelitian ini difokuskan kajiannya pada tindak tutur ilokusi. Tindak tutur ilokusi merupakan sebuah tindakan dalam mengerjakan sesuatu dengan tujuan, fungsi, dan maksud tertentu (Wahyuni, Retnowaty, \& Ratnawati, 2018). Tindak tutur ilokusi berfungsi menyatakan suatu maksud dan dapat memberikan efek dari tuturan yang diujarkan oleh penutur kepada mitra tutur (Zamain \& Irma, 2020). Secara umum tindak tutur ilokusi dapat dikategorikan menjadi 5 jenis, yaitu ekspresif, direktif, asertif, deklaratif, dan komisif (Searle dalam Sagita dan Setiawan, 2019).

Sejauh penelusuran penulis, video podcast Deddy Corbuzier bersama Syekh Ali Jaber belum pernah dikaji oleh peneliti lainnya. Adapun penelitian terhadap tindak tutur ilokusi sudah pernah dilakukan oleh peneliti sebelumnya. Pertama, penelitian oleh Widyawati dan Utomo (2020) dengan judul "Tindak Tutur Ilokusi dalam Video Podcast Deddy Corbuzier dan Najwa Shihab pada Media Sosial Youtube", penelitian ini menitikberatkan kajiannya pada bentuk tindak tutur ilokusi pada video podcast Deddy Corbuzier dan Najwa Shihab. Hasil penelitian menunjukkan terdapat tindak tutur ekspresif, direktif, asertif, komisif, dan deklaratif.

Kedua, penelitian oleh Sagita dan Setiawan (2019) dengan judul "Tindak Tutur Ilokusi Ridwan Kamil dalam Talkshow Insight di CNN Indonesia", orientasi dalam penelitian ini pada aspek bentuk dan jenis tuturan ilokusi. Hasil penelitian menunjukkan bentuk tindak tutur ilokusi yaitu deklaratif, imperatif dan interogatif, dan jenis tindak tutur ilokusi ditemukan 4 jenis, asertif, direktif, komisif, dan ekspresif. Ketiga, oleh Stambo dan Ramadhan (2019) dengan judul "Tindak Tutur Ilokusi Pendakwah dalam Program Damai Indonesia di TV One", penelitian ini memfokuskan analisisnya pada jenis tindak tutur ilokusi yang digunakan pendakwah. Hasil penelitian menunjukkan jenis tindak tutur terdapat 5 jenis, yaitu asertif, direktif, komisif, ekspresif, dan deklarasi. 
Penelitian sebelumnya dan penelitian ini memiliki kesamaan pada aspek kajian yaitu jenis tindak tutur ilokusi. Adapun yang membedakaan adalah objek kajian yaitu video podcast Deddy Corbuzier bersama Syekh Ali Jaber. Selain itu, dalam penelitian ini mendiskusikan nilai pendidikan karakter. Dengan demikian, fokus penelitian ini adalah. (1) Mendeskripsikan jenis tindak tutur ilokusi dalam video podcast Deddy Corbuzier bersama Syekh Ali Jaber. (2) Mendeskripsikan nilai pendidikan karakter yang terdapat dalam tuturan dalam video podcast Deddy Corbuzier bersama Syekh Ali Jaber.

\section{METODOLOGI PENELITIAN}

Penelitian ini menggunakan pendekatan deskriptif kualitatif, karena bertujuan mengungkapkan fenomena tindak tutur ilokusi dan nilai pendidikan karakter dalam video podcast Deddy Corbuzier bersama Syekh Ali Jaber, dengan cara deskriptif dalam bentuk kata-kata. Pendekatan deskriptif merupakan pendekatan yang digunakan untuk menjelaskan suatu fenomena secara sistematis, faktual, dan akurat dengan cara deskripsi (Rukajat, 2018). Sumber data penelitian adalah tuturan yang dituturkan oleh Deddy Corbuzier, Syekh Ali Jaber, dan Gus Mifta dalam video Podcast Deddy Corbuzier bersama Syekh Ali Jaber di kanal youtube Deddy Corbuzier. Podcast ini ditayangkan pada tanggal 16 September 2020 dengan judul "Syekh Ali Jaber, Saya Pasrah. Deddy Corbuzier Podcast". Adapun data penelitian berupa kalimat yang mencerminkan tindak tutur ilokusi dan nilai pendidikan karakter.

Teknik pengumpulan data menggunakan teknik observasi pada video Podcast Deddy Corbuzier bersama Syekh Ali Jaber, yang kemudian data dikelompokkan untuk dilakukan analisis data. Pada proses analisis data dilakukan transkip rekaman berdasarkan tindak tutur ilokusi dan nilai pendidikan karakter. Adapun teknik analisis data dalam penelitian ini meliputi tahapan (1) reduksi data, (2) penyajian data, dan (3) penarikan kesimpulan/verifikasi, yang sesuai model Miles dan Huberman (Mardawani, 2020). Langkah terakhir adalah validasi data dengan cara, (1) ketekunan pengamatan untuk menemukan data yang relevan dengan rumusan masalah, dan (2) berdiskusi dengan beberapa ahli.

\section{HASIL DAN PEMBAHASAN}

Berdasarkan hasil penelitian ditemukan jenis tindak tutur ilokusi dalam video podcast Deddy Corbuzier bersama Syekh Ali Jaber, yaitu sebagai berikut: (1) tindak ujaran asertif, (2) tindak ujaran direktif, (3) tindak ujaran komisif, (4) dan ekspresif. Selain itu, tuturan yang digunakan oleh Deddy Corbuzier, Syekh Ali Jaber, dan Gus Miftah mengandung nilai-nilai pendidikan karakter, seperti (5) karakter peduli sosial, (6) karakter religius, (7) karakter jujur, (8) karakter toleransi, (9) karakter cinta tanah air, (10) karakter kreatif, (11) karakter demokrasi, dan (12) karakter cinta damai. Hal tersebut dijelaskan sebagai berikut.

\section{Jenis Tindak Tutur Ilokusi dalam Video Podcast Deddy Corbuzier bersama Syekh Ali Jaber}

Ditinjau dari jenisnya tindak tutur ilokusi dapat diklasifakasikan menjadi beberapa kategori (Searle dalam Sagita dan Setiawan, 2019), yaitu sebagai berikut. (1) Tindak tutur asertif merupakan tindak tutur yang berkaitan dengan kebenaran proporsi yang diujarkan oleh penutur, sehingga membawa terhadap suatu kebenaran. (2) Tindak tutur direktif merupakan tindak tutur yang dapat mempengaruhi atau memberikan efek pada mitra tutur untuk melakukan apa yang diujarkan oleh penutur. (3) Tindak tutur komisif merupakan tindak tutur yang berhubungan dengan tindakan di masa yang akan datang. (4) Tindak tutur ekspresif merupakan tindak tutur yang diujarkan penutur untuk merepresentasikan psikologis penutur. (5) Tindak tutur deklaratif merupakan tindak tutur yang dapat mempengaruhi dan mengubah suatu peristiwa, dan lazimnya tindak tutur ini dilakukan dalam lembaga-lembaga formal. Adapun dalam penelitian ini hanya ditemukan 4 jenis tindak tutur ilokusi sebagai berikut.

\section{Tindak Tutur Asertif}

Dalam kegiatan interaksi (dialog) pada video podcast Deddy Corbuzeir bersama Syekh Ali Jaber ditemukan jenis tindak tutur asertif dengan fungsi memberitahukan dan mengutarakan 
pendapat. Hal tersebut dapat dibuktikan pada data berikut.

Data (1) dialog menit 1:51-2:14

Syekh Ali Jaber: "karena selama di Indonesia sudah mau dua belas tahun."

Gus Mifta: "dua belas tahun ya Syekh."

Syekh Ali Jaber: "Iya, enggak pernah saya apa, menyakiti orang, mau agama manapun atau kelompok manapun. Endak pernah saya suka bahas. Latar belakang, jadi saya selalu berusaha menjadi orang baik. Terutama suci hati."

Pada data (1) tuturan Syekh Ali Jaber kepada mitra tuturnya yaitu Deddy Cobuzeir dan Gus Mifta dapat dikategorikan sebagai tindak tutur asertif dengan verba memberitahukan. Tuturan tersebut bertujuan untuk memberitahukan kebenaran bahwa Syekh Ali Jaber sudah tinggal di Indonesia dalam kurun waktu hampir dua belas tahun. Dilihat berdasarkan isi, tindak tutur asertif tersebut menjelaskan bahwa selama tinggal di Indonesia Syekh Ali Jaber berusaha menjadi warga Indonesia yang baik dengan cara menghindari konflik baik dengan agama maupun kelompok lain (organisasi masyarakat, dan lain sebagainya). Ujaran tersebut mengandung kebenaran bahwa Syekh Ali Jaber mulai tinggal di Indonesia pada tahun 2008 dan resmi menjadi warga negara Indonesia pada tahun 2012 (Persada, 2021). Selain itu, selama tinggal di Indonesia belum ada catatan yang menunjukkan dan membuktikan Syekh Ali Jaber terlibat dalam konflik manapun. Dengan demikian, tuturan tersebut merupakan tindak tutur asertif karena mengandung kebenaran yang diujarkan oleh penutur.

Data (2) dialog menit 16:00-17:37

Syekh Ali Jaber: "enddak begini, saya sebenarnya melihat. Saya mempercayai satu hal, tidak ada sesuatu yang terjadi kebetulan. Semua ditentukan oleh Allah. bahkan kata ... kita lari dari takdir ke takdir.
Jadi apa yang kita buat, endak bakalan, endak bakal bisa merubah takdir. Saya percaya ketika kita ... dalam takdir, endak akan berubah. ..."

Pada data (2) tuturan dapat dikategorikan sebagai tindak tutur asertif dengan verba mengutarakan pendapat, yaitu tindak tutur untuk mengungkapkan pendapat tentang suatu kebenaran yang diyakni oleh penutur (Syekh Ali Jaber). Tindak tutur asertif tersebut menggunakan verba mengutarakan pendapat, yaitu Syekh Ali Jaber mengutarakan pendapatnya tentang kebenaran takdir dari Allah. Dilihat berdasarkan isi tuturan, Syekh Ali Jaber menjelaskan keyakinan tentang musibah yang dialami sudah ditakdirkan atas izin Allah, dan bukan datang secara kebetulan. Secara fakta, dalam perspektif agama Islam datangnya takdir seperti kematian, musibah, rezeki, dan jodoh sudah diatur oleh Allah. Tuturan tersebut tentang kebenaran/keyakinan Syekh Ali Jaber terhadap takdir Allah memberikan manfaat dalam kehidupan sehari-hari, karena seseorang yang menyakini takdir Allah, maka mudah bersyukur, pemaaf, dan rendah hati. Dengan demikian, ujaran di atas merupakan tindak tutur asertif, karena mengandung kebenaran yang diujarkan oleh penutur.

Berdasarkan hasil analisis data, tindak tutur asertif yang digunakan dalam kegiatan komunikasi tersebut, yaitu dalam konteks memberikan informasi kepada kawan tutur dan mengutarakan pendapat. Indikator tuturan asertif yang dilakukan oleh penutur dibuktikan dengan fakta (kebenaran) yang diujarkan. Sejalan dengan pendapat Jahdiah (2021), bahwa tindak tutur asertif berisi kebenaran proposisi yang diungkapkan penutur.

Hasil penelitian ini relevan dengan penelitian yang dilakukan oleh Isnaeni, Lukman, \& Saleh (2021), menunjukkan bahwa tindak tutur asertif pada fungsi memberitahukan bertujuan untuk memberikan informasi kepada kawan tutur yang belum diketahuinya. Selain itu, tuturan asertif pada fungsi mengutarakan pendapat (menyatakan) bertujuan menjelaskan kembali terkait konteks pembicaraan kepada kawan tutur dari perspektif penutur. Hal tersebut sesuai dengan hasil penelitian ini. 


\section{Tindak Tutur Direktif}

Dalam video podcast Deddy Corbuzeir bersama Syekh Ali Jaber ditemukan jenis tindak tutur direktif dengan fungsi pertanyaan, menasihati, perintah, permintaan, dan menyarankan. Hal tersebut dapat dilihat pada data di bawah ini.

Data (3) dialog menit 7:36-7:42

Deddy Corbuzeir: "tapi Syekh liat itu pisau tidak?

Syekh Ali Jaber: "enddak, enddak saya perhatikan. Masih masih belum belum membayangkan ada apa."

Pada data (3) tuturan dapat dikategorikan sebagai tindak tutur direktif dengan verba pertanyaan, yaitu tindak tutur yang mendorong mitra tutur untuk melakukan sesuatu berdasarkan pertanyaan yang disampaikan penutur. Penutur (Deddy Cobuzier) bertanya tentang alat yang digunakan pada saat kejadian penusukan yang dialami mitra tutur (Syekh Ali Jaber). Tuturan asertif yang sampaikan penutur berupa 'pertanyaan' mendapatkan respons dari mitra tutur. Mitra tutur menjawab bahwa pada awal kejadian tidak menyadari adanya pisau. Berdasarkan hal tersebut dapat disimpulkan bahwa ujaran di atas merupakan tindak tutur asertif, karena mitra tutur memberikan jawaban atau melakukan keinginan penutur yang bertanya tentang alat penusukan (pisau).

Data (4) dialog menit 23:41-24:37

Syekh Ali Jaber: "dimaki, Allah takdirkan ujian. Udah selesai. Enddak ada satu kata keluar dari mulut orang, kalau belum dizinkan oleh Allah. Kita harus bisa belajar pasrah diri kepada Allah. jangan hanya kita berbicara seperti diiftitah kita. Salat kulinnasalati wamasuki wamahyaya amamatilillah, mana buktinya? Salatku ibahku matiku dan hidupku Lillah, mana buktinya? Sehari-hari, sehari-hari beraktivitas disitu terlihat bukti. Allah tidak menerima dari ucapan saja. ..."

Pada data (4) tuturan dapat dikategorikan sebagai tindak tutur direktif dengan verba menasihati, yaitu tindak tutur yang dilakukan untuk memberikan nasihat kepada mitra tutur dalam berperilaku yang baik. Penutur (Syekh Ali Jaber) menasihati mitra tutur (Deddy Corbuzier dan Gus Mifta) agar selalu senantiasa berpasrah diri kepada Allah, baik dalam keadaan yang senang atau susah. Selain itu, bentuk keimanan seseorang kepada Allah tidak hanya diukur berdasarkan ucapan saja, melainkan diikuti dengan perbuatan yang baik. Hal ini dapat memberikan dampak positif dalam membangun ikatan yang kuat antara seorang hamba dengan Tuhannya, dan manusia dengan sesama. Maka dengan adanya ujaran tersebut, bermaksud agar mitra tutur dapat meresapi informasi yang disampaikan oleh penutur dan direalisasikan dalam menjalankan aktivitas sehari-hari. Berdasarkan hal tersebut dapat disimpulkan tuturan penutur di atas merupakan tindak tutur direktif, karena berupa ajakan kepada mitra tutur untuk melakukan kebaikan dan disampaikan melalui verba nasihat.

Data (5): dialog menit 46:50-47:29

Syekh Ali Jaber: "jangan meniru!. Saya tekankan kepada Jemaah begini, masuk ke mesjib langkah kaki yang kanan, karna apa? Bukan karna itu sunnah, bukan karna ini hal baik, tapi karna ingin meniru Nabi Muhammad. Sampek anak-anak, saya bilang kalau biasanya kalau kita mau beri anak sesuatu. Namanya anak-anak kadangkadang suka ambil bagi kiri. Kita kan sering mengingatkan, eeeh mana tangan yang bagus, mana tangan yang kanan kan. Saya bilang boleh enggak dirubahkan kata itu. Terus apa? Eeh mana tangan yang disukai Nabi Muhammad. Supaya anak kita dari kecil tertanam segala perilaku dia meniru Nabi Muhammad. Walaupun dia tidak kenal Nabi Muhammad siapa."

Pada data (5) tuturan dapat dikategorikan sebagai tindak tutur direktif dengan verba perintah, yaitu tindak tutur untuk memberikan sebuah perintah kepada mitra tutur agar melakukan suatu perbuatan yang merepresentasikan perbuatan Nabi Muhammad. 
Dilihat berdasarkan bentuknya tuturan pada kata "jangan meniru!" mengandung makna memerintah, karena terdapat tanda (!) dan penutur menggunakan intonasi tinggi. Dalam hal ini Syekh Ali Jaber memerintahkan mitra tuturnya dalam melakukan aktivitas sehari-hari harus mencontoh Nabi Muhammad. Dimulai dari kebiasaan yang sederhana, seperti etika memasuki masjid menggunakan kaki kanan terlebih dahulu. Perbuatan tersebut juga dapat diterapkan pada anak-anak, karena akan membentuk spiritualitas yang baik dan tertanam kecintaan kepada Nabi Muhammad sejak dini. Adapun secara realitas, pembentukan karakter anak yang berkualitas bergantung pada pola asuh orang tua. Dengan demikian dapat disimpulkan bahwa tuturan tersebut merupakan tindak tutur direktif, karena mengandung sebuah perintah agar mitra tutur melakukan yang diujarkan penutur.

Data (6): dialog menit 48:00-49:43

Syekh Ali Jaber: “... Jadi saya ingin masyarakat ini menghidupkan Nabi Muhammad dihatinya. Nabi Muhammad sudah wafat 1400 , tapi bagi saya Nabi Muhammad masih ada, dihati. Saya melangkah Nabi Muhammad, makan Nabi Muhammad, Wuduk Nabi Muhammad, berbicara Nabi Muhammad, berakhlak Nabi Muhammad, berpakaian Nabi Muhammad, hubungan saya bersama non muslim Nabi Muhammad, Nabi Muhammad juga dengan tetangganya Yahudi dengan tetangganya non muslim kuffar qurais, cobak liat belajar. Nabi Muhammad sebenarnya luar biasa, saya hanya ingin mudahmudahan kalau Allah izinkan, saya dengan bisa meniru Nabi Muhammad S.W.A, saya selalu berdoa Yaallah mudah-mudahan saya bisa bertemu beliau dan bisa mendapatkan safaatnya. Karna Nabi Muhammad itu manusia yang paling suci, yang paling mulia. Jadi wajar kalau kita meniru, dia orang-orang yang sudah mendapatkan luar biasa fasilitas dari Allah, sampek saat ini, sampek titik ini bahkan sampek hari kiamat. Allah masih mempuji Nabi Muhammad."

Pada data (6) ujaran dapat dikategorikan sebagai tindak tutur direktif dengan verba permintaan, yaitu tindak tutur yang digunakan untuk meminta mitra tutur melakukan apa yang disampaikan oleh penutur. Hal tersebut dapat dilihat pada kalimat "jadi saya ingin masyarakat ini menghidupkan Nabi Muhammad dihatinya", kalimat ini menggambarkan sebuah makna permintaan dengan penegasan pada kata "ingin". Dalam hal ini Syekh Ali Jaber meminta kepada mitra tutur (secara umum masyarakat) untuk selalu mencintai dan menanamkan Nabi Muhammad dihatinya. Realisasi bentuk kecintaan kepada Nabi Muhammad yang dilakukan oleh Syekh Ali Jaber sendiri, seperti dalam berinteraksi sosial dan melakukan kegiatan sehari-hari. Oleh karena itu dapat ditarik benang putih bahwa ujaran tersebut merupakan tindak tutur direktif, karena mengandung makna permintaan atau ajakan kepada mitra tutur untuk melakukan sesuatu.

Data (7): dialog menit 55:12-56:18

Syekh Ali Jaber: "Udah sampaikan apa adanya, dan insaallah saya yakin kejadian ini mudah-mudahan menyadarkan ummat. Intinya jangan terpancin emosi, apa yang terjadi apapun keputusan nanti oleh aparat kepolisian, saya percaya sepenuhnya. ..."

Pada data (7) tuturan dapat dikategorikan sebagai tindak tutur direktif dengan verba menyarankan, yaitu tuturan untuk memberikan sebuah saran kepada mitra tuturnya dan pada dirinya sendiri. Syekh Ali Jaber sebagai penutur menyarankan kepada masyarakat untuk tidak terpancing emosi atau melakukan tindakan kekerasan, seperti aksi protes (demo) terhadap keputusan yang akan dikeluarkan oleh aparat polisi. Syekh Ali Jaber sepenuhnya memercai segala bentuk keputusan pihak berwenang. Oleh karena itu, Syekh Ali Jaber menyarankan kepada mitra tuturnya agar lebih kondusif, jangan menggunakan emosi dalam menyikapi kasus yang terjadi. Dari hal tersebut dapat disimpulkan tuturan merupakan tindak tutur direktif, karena 
memberikan saran kepada mitra tutur untuk melakukan apa disampaikan penutur.

Berdasarkan hasil analisis data, tuturan yang dilakukan oleh peserta tutur menggunakan tindak tutur direktif dalam konteks memberikan pertanyaan, menasihati, perintah, permintaan, dan menyarankan. Pemakaian tuturan asertif yang dilakukan oleh penutur dapat dibuktikan dengan kalimat tanya dan perintah, sehingga memberikan pengaruh kepada mitra tutur untuk melakukan apa yang disampaikan oleh penutur. Hal tersebut sesuai dengan pendapat Islamiati, Arianti, \& Gunawan (2020), menyatakan bahwa pemakaian tindak tutur direktif bertujuan memberikan efek tindakan sesuai keinginan penutur.

Untuk membuktikan hasil temuan, maka dibandingkan dengan penelitian yang relevan. Dalam hal ini penelitian yang dilakukan oleh Oktapiantama \& Utomo (2021), menunjukkan penggunaan tindak tutur direktif dalam sebuah tuturan bermaksud mengekspresikan kehendak penutur, sehingga mitra tutur memberikan respons balik terhadap maksud tersebut baik berupa ujuran maupun sikap. Tindak tutur direktif mencangkup verba suruhan, perintah, desakan, permintaan, bujukan, permohonan, ajakan, persilahan, himbauan, permintaan izin, harapan, larangan, ucapan selamat, umpatan, dan anjuran. Adapun dalam penelitian ini hanya ditemukan pada verba pertanyaan, menasihati, perintah, permintaan, dan menyarankan. Hal tersebut dapat terjadi, karena komunikasi antara film dengan podcast memiliki perbedaan durasi waktu, sehingga pola komunikasi pada podcast cenderung lebih sederhana.

\section{Tindak Tutur Komisif}

Dalam video podcast Deddy Corbuzeir bersama Syekh Ali Jaber terdapat jenis tindak tutur komisif dengan fungsi penolakan dan penawaran. Hal tersebut dapat dilihat pada data berikut.

Data (8) dialog menit 2:15-3:23

Syekh Ali Jaber: "Endak mau hat, kadang-kadang ada orang suka membawa cerita, apalagi isinya gossip atau, udah-udah endak mau dengar. Saya endak mau dengar biar hati saya selamat. Kalau saya dengar apalagi jeritan orang atau fitnah orang pasti namanya manusia kebawa emosi, lebih baik tidak usa dengar. ..."

Pada data (8) tuturan dapat dikategorikan sebagai tindak tutur komisif dengan verba penolakan, yaitu tuturan yang mendorong penutur untuk melakukan aksi/tindakan penolakan. Dapat dilihat pada bentuk kata "endak", yang menjelaskan sebuah makna penolakan. Dalam hal ini, Syekh Ali Jaber menolak untuk mendengarkan sebuah gosip, karena ingin menjaga hatinya tetap bersih dan takut terpancing emosi. Secara fakta gosip sebagai cerita yang mengandung cerita negatif orang lain, tidak baik berkembang dalam lingkungan masyarakat. Hal tersebut dapat menimbulkan pertengkaran antara sesama, menjatuhkan orang lain, dan menurut pandangan Islam gosip dapat menyebabkan dosa. Oleh karena itu, masyarakat diimbau untuk mengindari gosip, dengan cara melakukan tindakan penolakan. Dengan demikian, tuturan penutur merupakan tindak tutur komisif, karena melakukan tindakan penolakan.

Data (9) dialog menit 3.25-4.25

Syekh Ali Jaber: “... Karna saya punya kebiasaan, apalagi dekat dengan anakanak kan kita ada acara bersama anakanak. Mangkanya saya sampaikan. Nak kamu mau hadiah apa? Saya ingin kasih sesuatulah gitu kenangkenangan. Dia bingung mau jawab apa, ya udah tanya ibumu, kamu ... (suaranya tidak jelas). Dia turun ke ibunya."

Pada data (9) tuturan dapat dikategorikan sebagai tindak tutur komisif dengan verba menawarkan, yaitu ujaran yang menawarkan atau memberikan sebuah pilihan kepada mitra tutur. Hal tersebut dapat dilihat pada bentuk klausa "nak kamu mau hadiah apa?", yang mengandung makna menawarkan. Tuturan menawarkan penutur diperjerlas pada kata "mau" kemudian diakhir klausa terdapat tanda (?). Dalam hal ini konteks tuturan yaitu penutur (Syekh Ali Jaber) menceritakan kronologi penusukan di acara wisuda. Saat kejadian, Syekh Ali Jaber 
menawarkan hadiah kepada salah satu anak yang hafiz Al-Qur.'an sebagai bentuk kenangkenangan. Dengan demikian, tuturan tersebut merupakan tindak tutur komisif, karena mengikat penuturnya untuk merealisasikan apa yang diujarkan yaitu menawarkan.

Berdasarkan hasil analisis data, tindak tutur komisif yang dilakukan peserta tutur dalam konteks memberikan penolakan dan penawaran. Ujaran tersebut direalisasikan dengan pemakain kalimat tanya dan seruan. Pemakaian tuturan komisif yang dilakukan oleh penutur dapat dibuktikan dengan ungkapan-ungkapan yang mengikat penuturnya untuk melakakukan yang diujarkan. Menurut Manuartawan, Hermawan, \& Sadyana (2019), tindak tutur komisif berisi ungkapan yang menuntut penuturnya melakukan sesuai yang diungkapkan dalam tuturanya.

Hasil temuan pada penelitian dapat diperkuat dengan penelitian yang relevan. Penelitian oleh Herfani \& Manaf (2020), hasil penelitian menunjukkan tindak tutur komisif dapat dikategorikan menjadi menawarkan, berjanji, berniat, bernazar, dan bersumpah. Selain itu, penelitian oleh Habiburrahman, Gani, \& Setiawan (2020), bentuk pemakaian tindak tutur komisif digunakan sebagai strategi menjanjikan, mengancam, memanjatkan doa, dan menawarkan. Kedua penelitian tersebut dilakukan pada konteks kegiatan bertutur dalam peristiwa politik (kampanye), sehingga yang dominan muncul yaitu tuturan komisif berjanji. Oleh karena itu, pemakaian tindak tutur komisif dilakukan dengan tujuan menarik simpati masyarakat dengan mengkampanyekan gagasan/ide dari penutur. Berbeda dengan penelitian ini, kegiatan tuturan dalam konteks dakwah. Sehingga hanya ditemukan tindak tutur komisif penolakan dan penawaran.

\section{Tindak Tutur Ekspresif}

Selain tindak tutur di atas, dalam video podcast Deddy Corbuzeir bersama Syekh Ali Jaber juga ditemukan jenis tindak tutur ekspresif dengan fungsi ucapan terima kasih, memuji, dan minta maaf. Hal tersebut dapat dilihat pada data berikut.

Data (10) dialog menit 1:20-1:44
Syekh Ali Jaber: "selamat malam. Selamat sejah tera untuk kita semuanya. Terima kasih mas Deddy tentang kesempatan ini, guru tercinta Gus Mifta. Alhamdullah. Pertama saya bersyukur kaddarallah walataf, takdir Allah itu sangat lembut dan Allah selamatkan. Dan bagi saya ini adalah pengalaman baru."

Pada data (10) tuturan dapat dikategorikan sebagai tindak tutur eskpresif dengan verba terima kasih, yaitu tindak tutur yang menyatakan perasaan (terima kasih) penutur atas kesempatan yang diberikan oleh mitra tutur. Dalam hal ini Syekh Ali Jaber berterima kasih kepada Deddy Corbuzeir dan Gus Mifta yang sudah mengundang ke acara podcast milik Deddy Corbuzeir. Selain itu, tuturan terima kasih juga merupakan ungkapkan kepada Allah, karena memberikan keselamatan pada Syekh Ali Jaber. Tindak tutur terima kasih ini terjadi karena penutur merasa senang dan tuturan disertai aspek kinestik sunyum. Berdasarkan hal tersebut, dapat disimpulkan bahwa tuturan di atas merupakan tindak tutur ekspresif.

Data (11) dialog menit 15:11-15:24

Gus Mifta: "iman beliau endak kayak kita bro, tawakalnya udah endak kayak kita. Dan firasatnya ini luar biasa, tadi beliau cerita. Setelah sekian lama beliau enggak pakai jubah hitam, kok pas di hari itu beliau pakai jubbah hitam. Tapi biasanya putih Syekh"

Pada data (11) ujaran dapat dikategorikan sebagai tindak tutur ekspresif dengan verba memuji, yaitu tindak tutur yang diungkapkan untuk memberikan pujian atas kelebihan dari mitra tutur. Penutur (Gus Mifta) memuji kualitas keimanan mitra tutur (Syekh Ali Jaber). Hal tersebut dilakukan karena Gus Mifta sangat kagum dengan sikap Syekh Ali Jaber yang mudah memberi maaf terhadap orang lain dan tidak menyimpan dendam. Selain itu, Gus Mifta juga kagum pada firasat Syekh Ali Jaber, ungkapan rasa bangga dituturkan dalam bentuk kata "luar biasa". Dengan demikian dapat disimpulkan ujaran tersebut merupakan tindak tutur ekspresif, 
karena tuturan diungkapkan untuk menggambarkan keadaan psikologis penutur yaitu perasaan kagum/memuji.

Data (12) dialog menit 56:27-56:53

Syekh Ali Jaber: "dan mohon maaf ya, sejak ada predar rekaman video ... (fonologi tidak jelas) anak itu. kamu dari apa namanya, eee yang dari kalang NU."

Gus Mifta: "ooo ini, iya ini yang perlu diklarifikasi Bro. jadi di video ketika apa namanya, tersangka ini ditangkap itu diakhir video ada kamu yang menyuruh siapa ya? Banzer ya? Ada bahasa seperti itu. dan sudah saya luruskan, jangan mengaitkan ini dengan siapa pun."

Pada data (12) tuturan dapat dikategorikan sebagai tindak tutur ekspresif dengan verba minta maaf, yaitu ujaran yang dinyatakan untuk mengungkapkan rasa penyesalan penutur. Dalam hal ini, Syekh Ali Jaber menuturkan bahwa sangat menyesal dengan adanya penyebaran video yang mengandung unsur sara. Ungkapan rasa penyesalan penutur direalisasikan dengan tindak tutur ekspresif, dilihat pada frasa "dan mohon maaf". Kesantunan tuturan penutur tersebut mencermikan rasa rendah hati. Dengan demikian, dapat disimpulkan bahwa tuturan di atas merupakan tindak tutur ekspresif, karena digunakan untuk mengungkapkan perasaan menyesal penutur.

Berdasarkan hasil analisis data, tindak tutur ekspresif yang digunakan penutur untuk mengungkapkan perasaannya kepada mitra tutur. Dalam penelitian ini, tuturan ekspresif yang digunakan dalam konteks memberikan ucapan terima kasih, memuji, dan minta maaf. Dengan adanya ujaran tersebut merepresentasikan nilainilai humanisme pada kegiatan tuturan tersebut. Pemakaian verba pada tindak tutur ekspresif mencangkup memaafkan, bersimpati, ikut prihatin, belasungkawa, dan lain sebagainya (Irma, 2017).

Untuk memperkuat hasil penelitian, maka peneliti membandingkan dengan penelitian yang relevan. Penelitian oleh Rudi \& Mujianto (2021), menunjukkan bahwa dengan adanya pemakaian tindak tutur ekspresif dalam kegiatan bertutur dapat memberikan dampak positif. Pemakaian tuturan ekspresif dalam konteks kegiatan pembelajaran dapat merangsang karakter yang baik terhadap peserta didik, seperti karakter percaya diri dan kreatif. Tetapi, dalam penelitian ini nilai-nilai karakter yang tampak pada tuturan ekspresif mengarah kepada karakter humanisme.

\section{Nilai Pendidikan Karakter dalam Tuturan dalam Video Podcast Deddy Corbuzeir bersama Syekh Ali Jaber}

Pendidikan karakter merupakan daya upaya untuk mendidik dan menanamkan kebiasaankebiasaan yang baik pada diri seseorang. Maka dengan adanya pendidikan karakter, seseorang diharapkan mempunyai personalitas watak yang baik dan selaras dengan norma-norma dilingkungan masyarakat. Menurut UndangUndang Nomor 20 Tahun 2003 Pasal 3 (dalam Ali, 2018), pengembangan pendidikan karakter diorentasikan pada karakter beriman dan bertakwa pada tuhan YME., sehat, berakhlak mulia, cakap, kreatif, berilmu, demokrasi dan bertanggung jawab. Kemudian dikembangkan lagi menjadi karakter religi, jujur, mandiri, disiplin, kreatif, cinta damai, kerja keras, toleransi, demokratis, tanggung jawab, rasa ingin tahu, cinta tanah air, semangat kebangsaan, menghargai prestasi, gemar membaca, peduli lingkungan, dan peduli sosial (Supriyadi, Hidayat, \& Tawaqal, 2020).

\section{Nilai Karakter Peduli Sosial}

Data (13) dialog menit 10:46-10:57

Deddy Corbuzeir: "dan saya pada saat itu ngelihat, akhirnya sipelaku ini dihakimi oleh jemaah."

Syekh Ali Jaber: "saya langsung berdiri di atasnya, jangan!" Gus Mifta: "dan justru beliau melerai, supaya tidak dipukuli sama Jemaah"

Bedasarkan data (13) terdapat nilai karakter peduli sosial, yaitu sikap atau karakter untuk memberikan bantuan/menolong pada orang lain dalam keadaan yang susah. Tuturan di atas menunjukkan adanya nilai karakter peduli sosial yang dicerminkan oleh Syekh Ali Jaber. Syekh Ali Jaber berusaha membela pelaku penusukan dari amukan jemaah. Meskipun Syekh Ali Jaber 
sebagai korban, tetapi memiliki perasaan peduli terhadap pelaku. Hal tersebut dilihat dari upaya Syekh Ali Jaber yang meminta jemaah untuk tidak memukul pelaku.

Rasa peduli sosial sangat esensial dalam kehidupan sehari-hari. Adanya rasa peduli sosial akan memberikan dampak positif terhadap lingkungan masyarakat, seperti mengurangi terjadinya konflik sosial, pembunuhan, perundungan dan kekerasan. Salah satunya yang dicerminkan oleh Syekh Ali Jaber, berusaha mencegah terjadinya kekerasan pada pelaku.

\section{Nilai Karakter Religius}

\section{Data (14) dialog menit 18:43-19:49}

Syekh Ali Jaber: "Sampek ada yang bisikin saya ini karena aliran ini. Udah saya enddak mau. Ada yang cara yang lebih baik, kalau tidak bisa bicara yang baik lebih baik diam. Saya belajar, saya berusaha apa yang diajarkan oleh Islam saya terapkan. Dan menurut saya kemulian ahklak seseorang bukan di saat santai. Tapi di uji kemulian akhlak seorang ketika musibah. Dan kita liat contoh kita Nabi Muhammad S.A.W pas lagi sujud dibuang kotoran di atas kepalanya, endak marah biasa saja. ...”

Berdasarkan data (14) menunjukkan nilai karakter religius, yaitu nilai yang mencerminkan perilaku, perkataan, dan perbuatan manusia yang berpedoman terhadap ketentuan Tuhannya dan agamanya (Mustari dalam Mumpuni, 2018). Sejalan dengan pengertian tersebut, nilai karakter religius dicerminkan oleh Syekh Ali Jaber. Pada tuturan di atas menjalaskan bahwa strategi Syekh Ali Jaber dalam menyikapi hasutan orang-orang yang menyuruh untuk membalas dendam kepada pelaku penusukan, tetapi tindakan yang diambil Syekh Ali Jaber dengan cara yang sesuai menurut ajaran Islam. Cara menyelesaikan suatu masalah menurut Islam yaitu diselesaikan dengan pikiran dingin bukan dengan amarah. Selain itu, Syekh Ali Jaber mencerminkan perilaku berpasrah diri kepada Allah atas segala musibah yang didapatkan. Menurut perspektif Syekh Ali Jaber, datangnya masalah tersebut yaitu, (1) bentuk ujian dari Allah, dan (2) meningkatlan ketaqwaannya kepada Allah. Dengan demikian dapat disimpulkan bahwa tuturan di atas mengandung nilai karakter religius.

Nilai Karakter Jujur

Data (15) dialog menit 22:09-22:20 Syekh Ali Jaber: "iya benar saya berbicara jujur, saya bicara apa adanya, bukan basa-basi, bukan karna apa. Saya tidak mau kasus ini dimanfaatkan oleh golongan tertentu atau."

Gus Mifta: "sekelompok orang."

Deddy Cobuzeir: "ataupun agama ya."

Berdasarkan data (15) menggambarkan nilai karakter jujur, yaitu perilaku yang ditampilkan seseorang berdasarkan kenyataan sebenarbenarnya (fakta), baik dari perkataan maupun perbuatan. Pada pernyataan di atas menunjukkan karakter jujur yang dicerminkan oleh Syekh Ali Jaber. Dalam hal ini, Syekh Ali Jaber menyampaikan tentang keinginannya agar masyarakat tidak mudah mempercayai berita hoaks dan kasusnya tidak dimanfaatkan oleh oknum-oknum yang tidak bertanggung jawab. Tuturan Syekh Ali Jaber tersebut disampaikan dengan sebenarnya bukan karena ada motif tertentu. Oleh karena itu, dapat disimpulkan pada tuturan tersebut mengandung nilai karakter jujur, karena Syekh Ali Jaber menyampaikan perkataannya dan keinginannya dengan jujur.

\section{Nilai Karakter Toleransi}

Data (16) dialog menit 22:21-22:37

Syekh Ali Jaber: “... (fonologis tidak jelas) agama, saya Alhamdulillah bersyukur dengan kejadian ini banyak yang kirim pesan. Ada yang sampek pendeta-pendeta, jadi saya terima. Mendoakan, memperhatikan kondisi dan keadaan saya."

Berdasarkan data (16) menggambarkan adanya nilai karakter toleransi, yaitu sikap yang mendorong seseorang untuk saling menghormati dan menghargai keanekaragaman ideologi di masyarakat, baik agama, suku, etnis. Dalam hal ini, nilai karakter toleransi ditunjukkan oleh Syekh 
Ali Jaber dan Pendeta. Pada pernyataan di atas menjalaskan bahwa Syekh Ali Jaber mendapatkan dukungan dari pendeta saat mengalami musibah. Dukungan yang diberikan oleh pendeta kepada Syekh Ali Jaber berupa ucapan doa yang disampaikan melalui pesan whatshaap. Secara fakta, kedua tokoh tersebut memiliki latar belakang berbeda dalam spiritualitasnya. Syekh Ali Jaber sebagai ulama Islam, sementara pendeta sebagai tokoh dalam agama non Islam, tetapi perbedaan tersebut tidak menghalingi untuk saling memberikan dukungan. Hal tersebut membuktikkan bahwa adanya nilai pendidikan karakter toleransi yang dibangun oleh Syekh Ali Jaber dan pendeta.

Dewasa ini, peranan nilai karakter toleransi sangat penting dalam menciptakan kehidupan masyarakat yang damai dan sejahtera. Dengan adanya nilai karakter toleransi dalam ruang lingkung masyarakat, maka problematika atau konflik seperti penistaan agama, dan kerusuhan antar suku maupun etnik dapat tertanggulangi dengan baik.

\section{Nilai Karakter Cinta Tanah Air}

Data (17) dialog menit 24:50-27:06

Syekh Ali Jaber: "sebenarnya saya harap, apalagi ketika saya dapat perhargaan dari Bapak SBY. Jadi warga negara Indonesia. Banyak orang ucapin selamat, selamat saya nangis. Yaallah saya terima penghargaan ini, tapi bagi saya beban. Bukan sebuah kemeriaan, kenapa saya begini, karna saya dengan kepercayaan itu menjadi warga negara Indonesia berarti saya sekarang terhitung sebagai rakyat Indonesia. Kalau saya tidak bisa menjaga nama baik negri Indonesia lebih baik cabut warga negara. Disitulah saya terbeban makanya saya berusaha terus. Kalau ada salah, saya dapat misal masukan dari kyai habib atau siapa, saya tidak ada rasa malu untuk segera minta maaf. Saya mau, saya orangnya terbuka suka minta maaf, dan saya tidak menunggu biarpun kemaren. ..."
Berdasarkan data (17) menunjukkan adanya nilai karakter cinta tanah air, yaitu pola pikir seseorang yang mencerminkan perasaan bangga, setia, dan peduli terhadap suatu bangsa, baik dari aspek bahasa, budaya, alam, ekonomi, sososial, dan politik (Nursalam, Nawir, Suardi, \& K, 2020). Sejalan dengan pengertian tersebut, dalam video Podcast Deddy Corbuzier bersama Syekh Ali Jaber terdapat nilai karakter cinta tanah air yang direpresentasikan oleh Syekh Ali Jaber. Syekh Ali Jaber sangat terharu (bangga) saat menjadi warga negara Indonesia. Oleh karena itu, Syekh Ali Jaber memiliki rasa tanggung jawab untuk dapat menjaga nama baik bangsa Indonesia. Perasaan tersebut disebabkan karena ada rasa peduli dan kesetian Syekh Ali Jaber pada bangsa Indonesia. Dengan demikian, tuturan di atas membuktikkan adanya nilai karakter cinta tanah air.

\section{Nilai Karakter Kreatif}

Data (18) dialog menit 28:22-28:37 Syekh Ali Jaber: "kita memberikan nasihat. Saya sebenarnya melihat mas Deddy bagus baik, nampaknya kalau bisa jangan seperti ini lebih baik." Gus Mifta: "pemilihan diksi kata Bro." Syekh Ali Jaber: "jadi memilih kata yang bisa menenangkan hati."

Berdasarkan data (18) menggambarkan bahwa karakter kreatif yang dicerminkan oleh Syekh Ali Jaber dalam memberikan nasihat kepada orang lain dengan cara tuturan yang sopan. Hal tersebut dapat dilihat pada kalimat saya sebenarnya melihat mas Deddy bagus baik, nampaknya kalau bisa jangan seperti ini lebih baik. Kalimat tersebut dituturkan dengan cara memberikan kesan/makna positif, kemudian disertai masukan/nasihat. Tuturan dilakukan oleh Syekh Ali Jaber bertujuan agar mitra tutur dapat menerima maksud yang ingin disampaikan.

Pada dasarnya kegiatan berkomunikasi baik dalam konteks memberikan nasihat kepada orang lain, sangat penting untuk memperhatikan pemilihan kata yang baik. Artinya, penutur membutuhuhkan daya kritis dan kreatif dalam mengelolah diksi yang baik dan sopan. Hal tersebut, dilakukan agar apa yang disampaikan mudah dipahami dan tidak menyinggung perasaan mitra tutur.

Nilai Pendidikan Karakter Pada Tindak Tutur Ilukosi dalam Podcast Deddy Corbuzeir 103 Bersama Syekh Ali Jaber 
Nilai Karakter Demokrasi

Data (19) dialog menit 31:41-33:50

Syekh Ali Jaber: “... Yaudah kalau urusan sama orang jangan menghakimi orang. Saya termasuk komunitas, saya sering bilang jangan pandangi wanita yang belum berjilbab, jangan pandangi dia buruk. Barang kali dia punya dua rakaat tahajjud disisi Allah, bisa menyebabkan terampuni semua dosanya. Kita tidak tau urusan manusia sama Allah, masing-masing punya rahasia sama Allah. ..."

Berdasarkan data (19) menggambarkan adanya nilai karakter demokrasi, yaitu pola pikir seseorang dalam bertindak serta menilai kesetaraan/kesamaan hak antara dirinya dan orang lain (Nursalam et al., 2020). Nilai karakter demokrasi dalam video Podcast Deddy Courbuzier bersama Syekh Ali Jaber dicerminkan oleh Syekh Ali Jaber saat memberikan nasihat kepada masyarakat. Nasihat atau pesan yang oleh Syekh Ali Jaber yaitu (1) jangan menghakimi orang lain (antara sesama), karena yang maha tahu atas kebenaran hanya Allah, dan (2) jangan menilai keburukan seseorang berdasarkan penampilan, salah satunya adalah wanita yang tidak berhijab. Tuturan di atas menjelaskan bahwa Syekh Ali Jaber memiliki pandangan bahwa semua manusia memiliki kesamaan untuk diperlakukan dengan baik, adil, dan dihargai. Perbuatan yang dilakukan oleh Syekh Ali Jaber mencerminkan adanya nilai karakter demokratis yang disampaikan melalui tuturan direktif (nasihat).

\section{Nilai Karakter Cinta Damai}

Data (20) dialog menit 56:58:57:28

Syekh Ali Jaber: "Makanya saya harap, eee video apapun ini bukan atas nama saya dan saya harap semua masyarakat tetap tenan. Mari kita menjaga kedamaian, menjaga kebersatuan, ada berbeda diantara kita, beda pandangan, beda pemahaman, itu wajar manusia. Beda otak, beda daya fikir, tapi jangan gara-gara perbadaan itu dijadikan permusuhan. Kita bisa hidup tenang, agar kita nyaman. Kita aman, nyaman, damai, pasti negeri kita aman."

Berdasarkan data (20) menggambarkan adanya nilai karakter cinta damai, yaitu sikap atau kepribadian seseorang yang mendorong dirinya untuk menghindari terjadinya konflik tehadap orang lain. Sejalan dengan hal tersebut, nilai karakter cinta damai ditunjukkan oleh Syekh Ali Jaber melalui tuturan direktif dengan mengajak masyarakat untuk tetap tenang dan tidak memperkeruh keadaan. Hal tesebut dapat dilihat pada kalimat "Mari kita menjaga kedamaian, menjaga kebersatuan, ...". Tuturan dilakukan oleh Syekh Ali Jaber bertujuan agar tercipta hubungan yang harmonis, damai, dan mempererat hubungan silaturahmi dalam masyarakat.

Secara keseluruhan nilai-nilai pendidikan karakter yang tampak dalam penelitian ini, yaitu karakter (1) peduli sosial, (2) religius, (3) jujur, (4) toleransi, (5) cinta tanah air, (6) kreatif, (7) demokrasi, dan (8) cinta damai. Nilai-nilai pendidikan karakter tersebut dewasa ini sangat esensial direalisasikan dalam kehidupan bermasyarakat. Dengan adanya pendidikan karakter dapat mengatasi problematik moral dalam lingkungan masyarakat, yang dapat direalisasikan melalui lembaga pendidikan (Suparwati, 2020).

Untuk memperkuat hasil analisis data, maka peneliti membandingkan dengan penelitian yang relevan. Peneliti oleh Marnetti (2020), menunjukkan bahwa nilai-nilai pendidikan karakter yang dominan pada tindak tutur lokusi, ilokusi, dan perlokusi adalah karakter peduli sosial dan rasa ingin tahu. Kedua karakter tersebut merepresentasikan karakter penuturnya. Berbeda dengan hasil penelitian ini, nilai pendidikan karakter yang dominan pada kegiatan tuturan tersebut, yakni nilai karakter religius. Hal tersebut dapat terjadi karena dipengaruhi oleh latar belakang penutur sebagai penceramah (ustaz) dalam Islam, dan konteks kegiatan tuturan.

\section{SIMPULAN}

Berdasarkan hasil analisis dan pembahasan dapat disimpulkan sebagai berikut. Pertama, jenis tindak tutur ilokusi yang ditemukan yaitu asertif, direktif, komisif, dan ekspresif. Setiap jenis tinda

Nilai Pendidikan Karakter Pada Tindak Tutur Ilukosi dalam Podcast Deddy Corbuzeir 104

Bersama Syekh Ali Jaber 
tutur memiliki verba yang berbeda, yaitu pada (1) tindak tutur aserif memiliki verba memberitahukan dan mengutarakan pendapat, (2) tindak tutur direktif memiliki verba pertanyaan, menasihati, perintah, permintaan, dan menyarankan, (3) tindak tutur komisif memiliki verba penolakan dan penawaran, dan (4) tindak tutur ekspresif memiliki verba ucapan terima kasih, memuji, dan minta maaf. Dari keempat jenis tindak tutur tersebut, verba yang banyak digunakan oleh penutur yaitu pada tindak tutur direktif.

Kedua, tindak tutur yang digunakan oleh penutur juga terdapat nilai pendidikan karakter yang dapat diimplentasikan dalam kehidupan sehari-hari, yaitu karakter peduli sosial, religius, jujur, toleransi, cinta tanah air, kreatif, demokrasi, dan cinta damai. Nilai pendidikan karakter tersebut sangat esensial dalam menciptakan iklim masyarakat yang sejahtera, damai, dan aman. Selain itu, delapan nilai pendidikan karakter juga dapat membentuk karakter genarasi muda. Dengan demikian, harapannya melalui nilai pendidikan karakter tersebut mampu menjawab tantangan zaman saat ini, yaitu menciptakan sumber daya manusia yang anggun secara moral dan unggul dalam intelektual.

\section{REFERENSI}

Ali, A. M. (2018). Pendidikan Karakter: Konsep dan Implementasinya. Jakarta: Kencana.

Aminah, S., Zuraida, \& Emilda. (2020). Bahasa Indonesia: untuk Perguruan Tinggi. Aceh: Lembaga Kita.

Arisandy, D., Rizkika, D. P., \& Astika, T. D. (2019). Eksistensi Bahasa Indonesia pada Generasi Milenial di Era Industri 4.0. Basastra: Jurnal Pendidikan Bahasa Dan Sastra Indonesia, 3(2), 247-251.

B, M. Y. (2020). Nilai Pendidikan Karakter pada Tindak Tutur (Speech Act) Lokusi, Ilokusi dan Perlokusi dalam Novel Cantik Itu Luka Karya Eka Kurniawan. Universitas Bung Hatta.

Banyumas, K., \& Zain, F. M. (2020). Video Viral Anak Perempuan Jadi Korban Perundungan, Hanya Bisa Menangis Terduduk di Tanah. Retrieved from Kompas.com website: https://regional.kompas.com/read/2020/12/3

0/13564111/video-viral-anak-perempuanjadi-korban-perundungan-hanya-bisamenangis?page $=$ all

Chanifah, N., \& Samsudin, A. (2019). Pendidikan Karakter Islami: Karakter Ulul Albab di dalam Al-Qur'an. Purwokerto Selatan: Pena Persada.

Ekawati, M. (2017). Kesantunan Semu pada Tindak Tutur Ekspresif Marah dalam Bahasa Indonesia. Adabiyyāt:Jurnal Bahasa Dan Sastra, 1(1), 1-22.

Habiburrahman, Gani, H. A. A., \& Setiawan, I. (2020). Strategi Tindak Tutur Komisif dalam Kampanye Politik Pilkada Serentak 2018. Jurnal Ilmiah Telaah, 5(1), 1-7.

Handayani, T. K., Megawati, S., \& Malia, L. (2016). Nilai-Nilai Karakter dalam Tindak Tutur Ilokusi dalam Buku Wir Besuchen Eine Moschee. Litera, 15(2), 305-318.

Hendriana, E. C., \& Jacobus, A. (2016). Implementasi Pendidikan Karakter di Sekolah Melalui Keteladanan dan Pembiasaan. Jurnal Pendidikan Dasar Indonesia, 1(2), 25-29.

Herfani, F. K., \& Manaf, N. A. (2020). Tindak Tutur Komisif dan Ekspresif dalam Debat Capres-Cawapres pada Pilpres 2019. Jurnal Bahasa Dan Sastra, 8(1), 36-51.

Indonesia, C. (2020). Polri Tangani 4.656 Kasus Siber, Pencemaran Nama Baik Dominan. Retrieved from CNN Indonesia website: https://www.cnnindonesia.com/nasional/202 01229094838-12-587280/polri-tangani4656-kasus-siber-pencemaran-nama-baikdominan

Irma, C. N. (2017). Tindak Tutur dan Fungsi Tuturan Ekspresif dalam Acara Rumah Perubahan Rhenald Kasali. Jurnal SAP, 1(3), 238-248. https://doi.org/10.30998/sap.v1i3.1181

Islam, S. (2017). Karakteristik Pendidikan Karakter; Menjawan Tantangan Multidimensional Melalui Implementasi Kurikulum 2013. Edureligia: Jurnal Pendidikan Agama Islam, 1(1), 89-101.

Islamiati, Arianti, R., \& Gunawan. (2020). Tindak Tutur Direktif dalam Film Keluarga Cemara Sutradara Yandy Laurens. Jurnal Pendidikan Rokania, 5(2), 258-270. 
Isnaeni, Lukman, \& Saleh, N. J. (2021). Tindak Tutur Asertif dalam Novel Calabai Karya Pepi Al-Bayqunie. JOEL: Journal of Educational and Language Research, 1(3), 193-208.

Jahdiah. (2021). Tindak Tutur Menolak: Studi Kesantunan Dalam Bahasa Banjar: Bintang Pustaka. Yogyakarta: Bintang Pustaka Madani.

Manuartawan, I. K. A., Hermawan, G. S., \& Sadyana, I. W. (2019). Tindak Tutur Komisif dalam Dorama Kazoku Game. Jurnal Pendidikan Bahasa Jepang Undiksha, 5(3), 315-323.

Mardawani. (2020). Praktis Penelitian Kualitatif: Teori Dasar dan Analisis Data dalam Perspektif Kualitatif. Yogyakarta: Deepublish.

Mumpuni, A. (2018). Integrasi Nilai Karakter dalam Buku Pelajaran: Analisis Konten Buku Teks Kurikulum 2013. Yogyakarta: Deepublish.

Nasrullah, R. (2018). Komunikasi Antar Budaya: di Era Budaya Siber. Jakarta: Prenada Media.

Nuramila. (2020). Kajian Pragmatik Tindak Tutur dalam Media Sosial. Banten: Yayasan Pendidikan dan Sosial Indonesia Maju.

Nurhadi, M. (2020). Keji! Guru Ngaji di Serang Tega Cabuli 5 Muridnya Sendiri. Retrieved from Suarabanten.id website: https://banten.suara.com/read/2020/12/29/1 63729/keji-guru-ngaji-di-serang-tegacabuli-5-muridnya-sendiri?page $=$ all

Nursalam, Nawir, M., Suardi, \& K, H. (2020). Model Pendidikan Karakter pada Mata Pelajaran Ilmu Pengetahuan Sosial di Sekolah Dasar. CV AA Rizky.

Oktapiantama, H., \& Utomo, A. P. Y. (2021). Analisis Tindak Tutur Direktif pada Film "Keluarga Cemara" Karya Yandy Laurens. Ghâncaran: Jurnal Pendidikan Bahasa Dan Sastra Indonesia, 2(2), 76-87.

Persada, G. (2021). Syekh Ali Jaber, Ulama asal Madinah yang Dianugerahi WNI oleh SBY. Retrieved 14 January 2021, from Kompastv website: https://www.kompas.tv/article/137845/syek h-ali-jaber-ulama-asal-madinah-yang- dianugerahi-wni-oleh-

sby?page=all\#: :text=Syekh Ali Jaber\%2C Ulama asal Madinah yang Dianugerahi WNI $\begin{array}{llll}\text { oleh } & \text { SBY,-Update } \quad \% 7 C & 14\end{array}$ Januari\&text=JAKARTA\%2C

KOMPAS.TV- Syekh,Indonesia (W

Pratama, D. A. N. (2020). Tantangan Karakter di Era Revolusi Industri 4.0 dalam Membentuk Kepribadian Muslim. Al-Tanzim: Jurnal Manajemen Pendidikan Islam, 3(1), 198226.

Purwanti, D. (2017). Pendidikan Karater Peduli Lingkungan dan Implementasinya. Dwijacendekia: Jurnal Riset Pedagogik, 1(2), 14-20.

Putri, N. I., \& Zulaeha, I. (2020). Tindak Tutur Direktif Humanis Langsung dalam Film "Anak Negeri Kisah Masa Kecil Ganjar Pranowo". Indonesian Language Education and Literature, 6(1), 58-68.

Ramadhanti, P. F., \& Mujianto, G. (2020). Impresi Tindak Tutur Tidak Langsung Tidak Literalterhadap Kepekaan Sosial Peserta Didikdalam Pembelajaran di MTs Surya Buana Malang. Estetik:Jurnal Bahasa Indonesia, 3(2), 171-184.

Rudi, \& Mujianto, G. (2021). Tuturan Ekspresif Pengajar BIPA dalam Pembelajaran Keterampilan Berbicara dengan Metode Dengar Pandang. Alinea: Jurnal Bahasa Sastra Dan Pengajaran, 10(1), 67-84.

Rukajat, A. (2018). Pendekatan Penelitian Kuantitatif: Quantitative Research Approach. Yogyakarta: Deepublish.

Sagita, V. R., \& Setiawan, T. (2019). Tindak Tutur Ilokusi Ridwan Kamil dalam Talkshow Insight di CNN Indonesia. Lensa: Kajian Kebahasaan, Kesusastraan, Dan Budaya, 9(2), 187-200.

Saputri, U. I., \& Rahmawati, L. E. (2020). Analisis bentuk Tindak Tutur Direktif dalam Dialog Film "Rembulan Tenggelam di Wajahmu" Karya Tere Liye. Jurnal KIBASP, 3(2), 249-260.

Stambo, R., \& Ramadhan, S. (2019). Tindak Tutur Ilokusi Pendakwah dalam Program Damai Indonesiaku di Tv One. BASINDO : Jurnal Kajian Bahasa, Sastra Indonesia, Dan Pembelajarannya, 3(2), 250-260.

Suparwati, D. (2020). Pentingnya Pendidikan 
Karakter Di Masa Pandemi Covid 19. Social, Humanities, and Educational Studies (SHEs): Conference Series, 3(4), 438- 443.

Suprayitno, A., \& Wahyudi, W. (2020). Pendidikan Karakter di Era Milenial. Yogyakarta: Deepublish.

Supriyadi, Hidayat, R., \& Tawaqal, R. (2020). Makna Budaya dan Nilai Pendidikan Karakter dalam Syair Ikan Terubuk. Jurnal Geram, 8(2), 1-10.

Wahyuni, S. T., Retnowaty, \& Ratnawati, I. I. (2018). Tindak Tutur Ilokusi pada Caption Akun Islami di Instagram. Basataka, 1(2), $11-18$.

Widyawati, N., \& Utomo, A. P. Y. (2020). Tindak Tutur Ilokusi dalam Video Podcast Deddy Corbuzier dan Najwa Shihab pada Media Sosial Youtube. Jurnal Ilmiah Telaah, 5(2), 18-27.

Zamain, R., \& Irma, C. N. (2020). Bentuk Tindak Tutur Ilokusi dalam Dialog Film Wanojakarya Rofie Al Joe. Jurnal Bindo Sastra, 4(2), 95-101. 